\title{
BLOOMING OF ROMANAS ROSE (ROSA RUGOSA THUNB.) CULTIVATED ON ASH DUMPS RECLAIMED WITH VARIOUS TECHNIQUES
}

\author{
Grzegorz Nowak, Jarosław Zieliński
}

\begin{abstract}
Department of Dendrology and Landscape Architecture, Agricultural University, Janosika 8, 71-424 Szczecin, Poland e-mail: gnowak@agro.ar.szczecin.pl
\end{abstract}

Received: 25.09.2007

S u m m a r y

This article presents the results of a study on the cultivation of romanas rose on ash, carried out between 2004 and 2006. The experiment involved two different substrata and five different fertile covers. The control group comprised of roses growing on native grounds and raw ash rock. The study measured the viability of the plants, number of flowers and fruit borne from these flowers.

This study showed that the techniques of reclamation applied in this study significantly influenced the examined characteristics of romanas rose. Fertile covers increased the growth and blooming, however the most desirable results were obtained when the cover consisted mostly of mineral matter.

Key words: Rosa rugosa, blooming, reclamation, burner wastes

\section{INTRODUCTION}

Ash, combustion by-product at coal power stations, is usually disposed of in dumps, which is highly harmful to the environment. Unfortunately, bioreclamation of the dumps is limited by the specific physicochemical properties of this type of waste $(\mathrm{N}$ i e d z wiecki and Meller, 1994; Gilewska, 2003; $\mathrm{Bacieczko}$ and Zieliński, 2004; Z i eliński and $\mathrm{Now}$ a k, 2004); its strong alkaline reaction, from $9 \mathrm{pH}$ to $12 \mathrm{pH}(\mathrm{N}$ i e dź w i e c ki and M e lle r, 1994), excludes the application of many plants. Hence, it is necessary to select appropriate species and a relevant reclamation technology.

Romanas rose (Rosa rugosa Thunb.) is a plant which is potentially useful in bioreclamation of dumps; it has low habitat requirements, is highly resistant to environmental pollution, and tolerant of alkaline reactions and high soil salinity. Bushes of this species have numerous root suckers and are tolerant of pruning, which is additionally useful in bioreclamation. As the dumps are often located in highly urbanized areas and frequently transformed into recreational areas, the selection of plants should also allow for decorative qualities, not only its usefulness for reclamation purposes $(\mathrm{K} 1 \mathrm{u}$ c zyński, 1979; Zi e lińs ki and Nowak, 2004; Now a k et al. 2005).

The aim of this study was to determine how various techniques of reclamation of dumps influence the production of generative organs of romanas rose.

\section{MATERIALS AND METHODS}

The study was carried out near Dolna Odra SA power station in Nowy Czarnów, at the dump reclamation site established in 2003 (B a c i e c z k o and Z i e lińs k i, 2003). It included the measurement of plants' viability (using the admittance method), the number of flowers, and the number of fruits borne from these flowers.

The experiment was conducted over a period of three years, between 2004 and 2006, and had a random subblock design, in three replications. One replication consisted of 8 plants. The preparation of the substrate was the first experimental factor, with two options:

,p" - raw ash

,p+" - ash supplemented with NPK fertilizers (60:70:70 $\left.\mathrm{kg} \times \mathrm{ha}^{-1}\right)$.

The type of the applied $40 \mathrm{~cm}$ deep fertile cover was the second experimental factor. There were five types of cover:

1. low peat and ash $(1: 3)$

2. bark of coniferous trees, sand, compost, ash (1:1:2:4)

3 . sand, compost, fermented sludge $(1: 1: 2)$

4. sand, ash, compost, fermented sludge (1:1:2:4)

5 . bark of coniferous trees, sand, compost, fermented sludge

$(1: 1: 2: 4)$

The control comprised of plants growing on the native grounds (gr) and raw ash rock (p).

The experiment involved plants multiplied generatively, planted in 2004 at a distance of $1.5 \mathrm{~m}$ (rows) x $0.5 \mathrm{~m}$ (plants), and pruned each year at the level of 0.2 $\mathrm{m}$. Between the rows of the roses, grass was planted, 
and the rows were subject to bare fallow with mechanical weed control. Standard maintenance activities were carried out during the experiment, however no watering or additional fertilizing took place.

The numerical data were analyzed with the Tuckey's test. The calculations were carried out using Statistica 7.1 PL software.

\section{RESULTS}

The study indicated that the reclamation techniques differed in their influence on the examined characteristics of romanas rose. The highest viability (mean $78.5 \mathrm{mcS} \times \mathrm{cm}^{-1}$ ) was achieved on the fertilized ash covered with the cover of bark of coniferous trees, sand, compost and ash $(p+2)-$ Fig. 1. The admittance coefficient values for the roses cultivated on sites p5, p4 and $p+3$ showed that they were in the same homogeneous group with $\mathrm{p}+2$, i.e. there were no statistically significant differences between the sites p5, p4 and $\mathrm{p}+3$ vs. $\mathrm{p}+2$. Interestingly, the control plants were significantly less viable than the experimental ones.

In this study, the most intense blooming was observed in the bushes growing on $\mathrm{p}+2$, i.e. fertilized ash covered with the cover of bark of coniferous trees, sand, compost and sand. The mean number of flowers was 142 (Fig. 2).

Bushes growing at the $\mathrm{p} 2$ site (covered with the cover of bark of coniferous trees, sand, compost, and ash) were observed to have the second largest number of flowers (93) and were a separate homogeneous group. The control bushes did not flower (p) or bloomed only sporadically (gr).

Fruits were borne from the flowers in different rates. The number of borne fruit in relation to the number of flowers ranged from $50 \%$ to $100 \%$ (Fig. 3). However, due to the high variability of this characteristic within the individual sites, no statistically significant influence of the reclamation techniques was observed.

\section{DISCUSSION}

This study shows that romanas rose is a species useful in the reclamation of ash dumps, what is confirmed by Maciorowski et al. (2007) investigations. In the experiment, the bushes growing at the reclamation sites were statistically significantly more viable and had a significantly higher intensity of blooming. The application of covers significantly improved the growth of the species, which is consistent with reports by other authors on various species of trees and bushes (K l u czyński，1979; Gi lewska，2003; Zieliński and Nowak, 2004; Nowak et al. 2005; M a ciorowski et al. 2007). More favorable effects were achieved when the cover consisted mostly of mineral content (sand and ash), but actually the application of any of the covers significantly increased the growth and blooming of the plants. The fertilization of

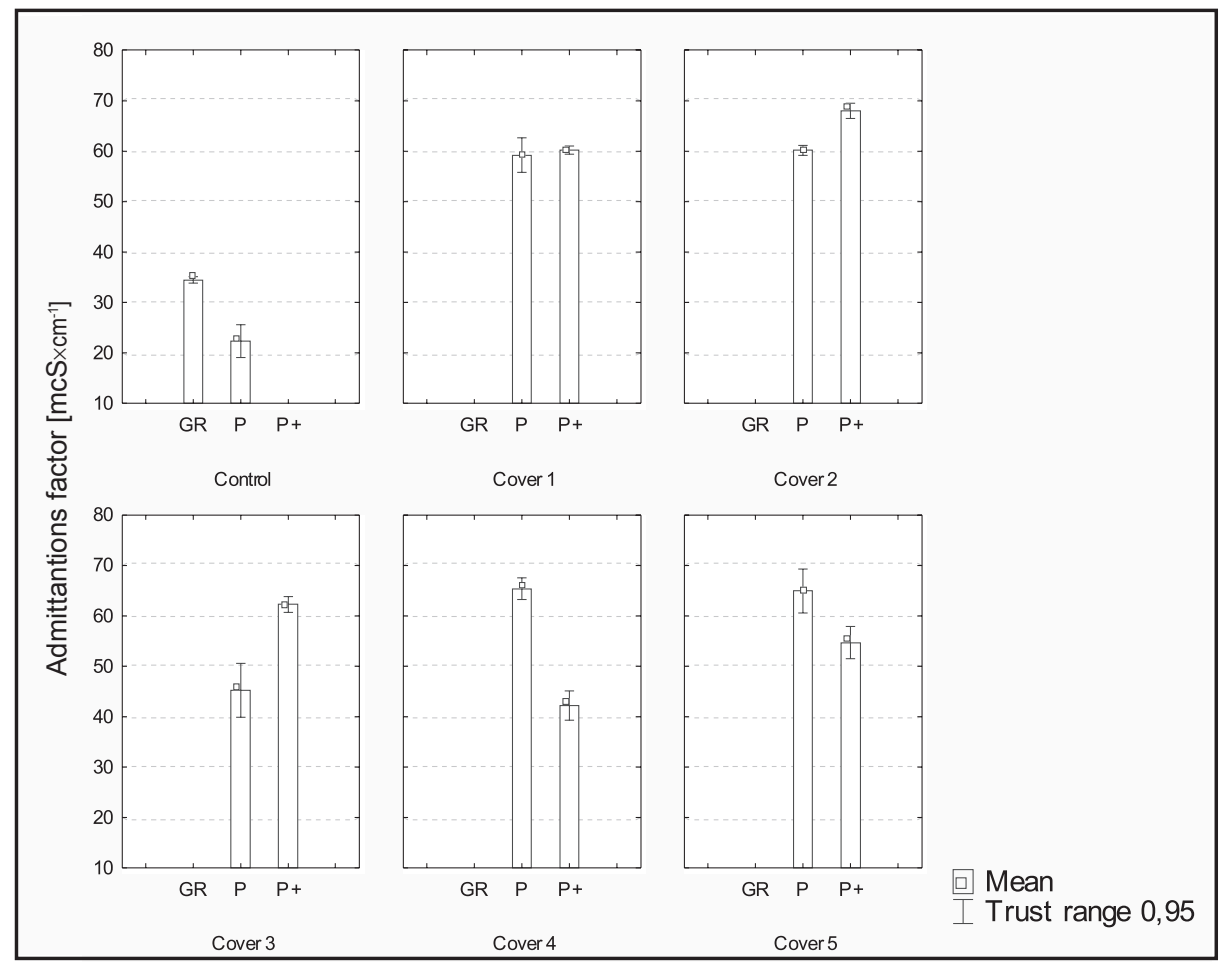

Fig. 1. Viability of romanas rose on ash reclaimed with different techniques. ( $\mathrm{Gr}-$ native ground, $\mathrm{P}-\mathrm{raw}$ ash, $\mathrm{P}+-\mathrm{ash}$ with NPK fertilizers). 


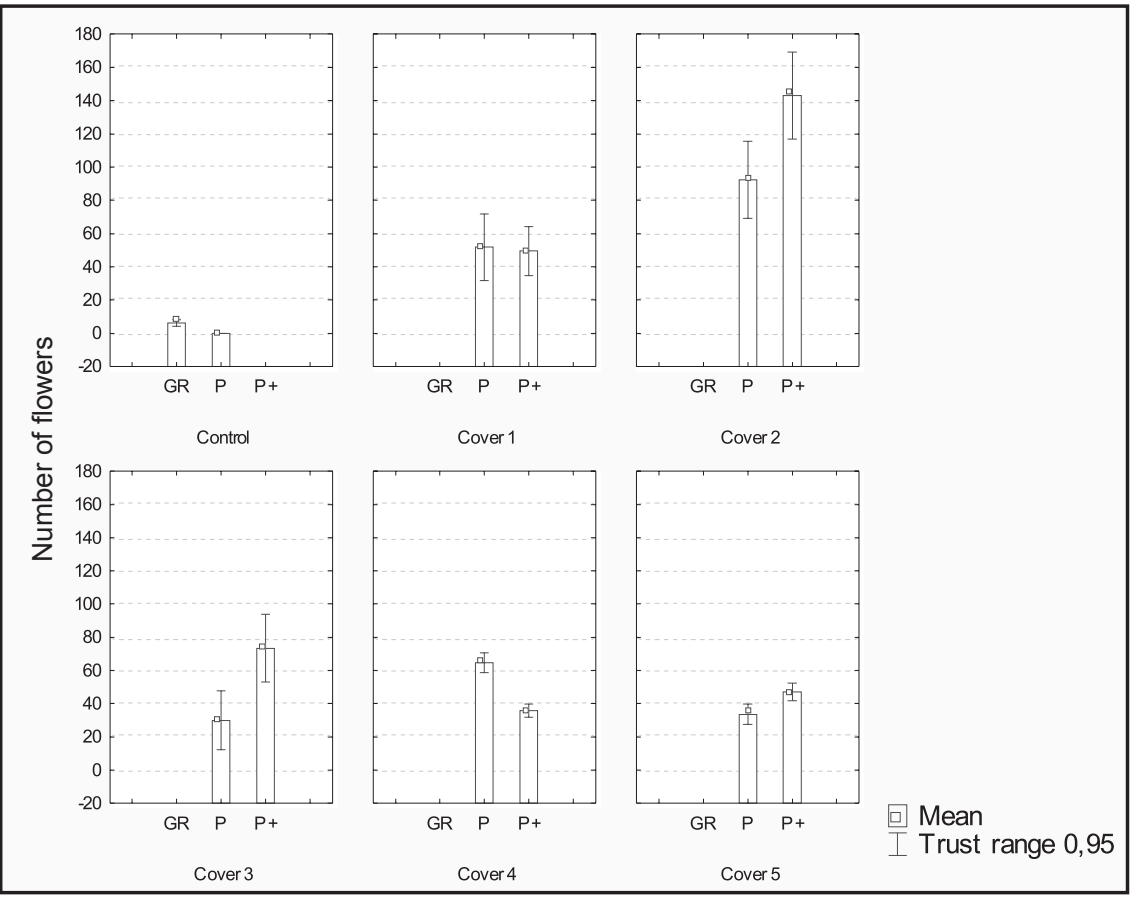

Fig. 2. Intensity of blooming of romanas rose cultivated on an ash dump reclaimed with different techniques. (Gr - native ground, $\mathrm{P}-$ raw ash, $\mathrm{P}+-$ ash with NPK fertilizers).

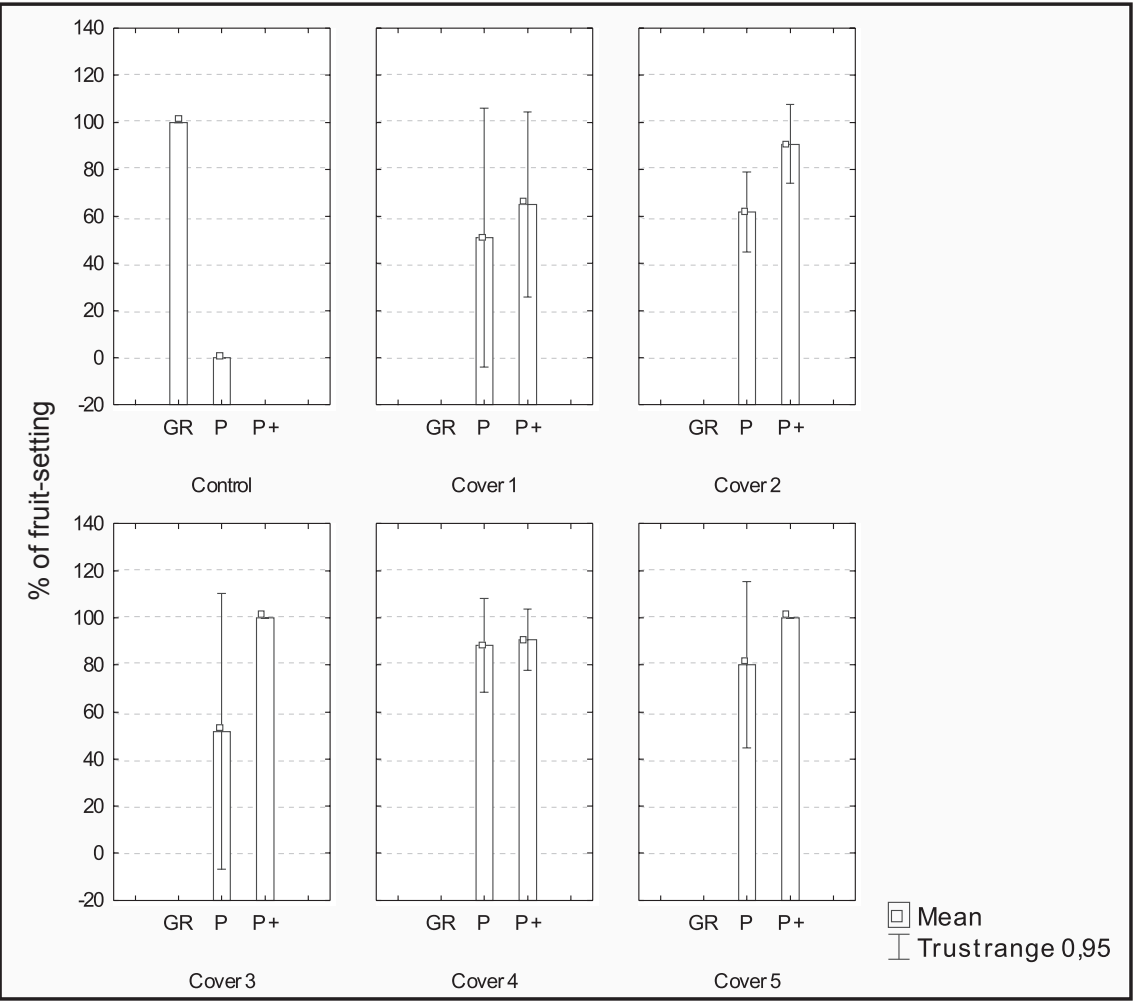

Fig. 3. Fructification in romanas rose bushes growing on ashes reclaimed with different techniques. (Gr - native ground, $\mathrm{P}-\mathrm{raw}$ ash, $\mathrm{P}+-$ ash with NPK fertilizers).

ash substratum exerted an advantageous influence on blooming of rose shrubs. The positive influence of fertilization on growing and blooming of different plants is a generally known effect and presented in numerous papers (f. ex. Lis - Kr zy sik, 1999; M a c i or ow s ki et al. 2007; Michałojć, 2007). The improvement of plant condition by the simultaneous use of top layers and fertilization of bottom layers was observed. It is compatible with results of G i l e w s k a (2003) investigations conducted in ZE PAK S.A. 


\section{CONCLUSIONS}

Followings conclusions come from the conducted investigations:

1. Reclamation methods have a significant impact on the vitality and abundance of blooming of Rosa rugosa shrubs.

2. The vitality and abundance of blooming of the investigated species growing on burner wastes were improved by organic matter addition to the top layer.

3. Romanas rose is a useful species to burner wastes site reclamation.

\section{REFERENCES}

Bacieczko W., Zieliński J., 2004. Wstępna ocena modelu rekultywacji odpadów paleniskowych Zespołu Elektrowni „Dolna Odra” S.A. w Nowym Czarnowie na podstawie Flory synantropijnej. / Preliminary estimation of the model of burner wastes recultivation from the group of Power Stations „Dolna Odra” S.A. in Nowe Czarnowo, based on studies of synanthropic flora. Fol. Univ. Agric. Stein. Agricultura: 9-18.

Gilewska M., 2003. Rekultywacja biologiczna gruntów składowisk popiołowych ZE PAK S.A. / Biological reclamation of grounds of PAK S.A. ash landfills, In: Materiały konferencyjne, Popioły $\mathrm{z}$ energetyki. Warszawa, 14-17 października 2003 r., Wyd. BiG sp. z o.o., Szczecin: $331-342$

Kluczyński B., 1979. Rozwój siewek wybranych gatunków drzew i krzewów na popiołach energetycznych z Elektrowni „Halemba” w doświadczeniu wazonowym. / The development of seedlings of selected tree and shrub species for recultivation of ash deposits from the „Halemba” Power Plant in a pot experiment. Arbor. Kórn. 24: 217-282.

Lis-Krzyścin A., 1999. Effect of nitrogen fertilization on growth and development of Pelargonium $X$ hortorum. I. Effect of different $\mathrm{N}$ levels, Wpływ różnych dawek azotu, Fol. Hort. 11 (1): 43-52.

Michałojć Z., 2007. Wpływ zróżnicowanego nawożenia azotem i potasem na wzrost, kwitnienie i walory dekoracyjne gomfreny (Gomphrena globosa L.). / The effect of nitrogen and potassium fertilization on growth, inflorescence and decorative value of gomphrena (Gomphrena globosa L.). Roczn. AR w Pozn. 41: 135-139.

Maciorowski R., Zieliński J., Nowak G., Stankowski S., 2007. Ocena wzrostu i procesów fotosyntetycznych perukowca podolskiego (Cotinus coggygira Scop.) i róży pomarszczonej (Rosa rugosa Thunb.) rosnących na modelu rekultywacyjnym w Elektrowni „Dolna Odra” w Nowym Czarnowie. / The estimation of growth and photosynthesis process of Smoke tree (Cotinus coggygria Scop.) and Romanas rose (Rosa rugosa Thunb.) growing on reclamation model in „Dolna Odra” Power Station in Nowe Czarnowo. In: Szymański K. [red.] Gospodarka odpadami komunalnymi, tom III, Komitet Chemii Analitycznej PAN, Koszalin: 259-266.
Nowak G., Zieliński J., Stankowski S., 2005. Wstępna ocena przydatności glediczii trójcieniowej Gleditshia tricanthos L. do rekultywacji składowisk odpadów paleniskowych ZE „Dolna Odra” S.A. w Nowym Czarnowie. / The preliminatory estimation of the usefulness of honey locust Gleditsia triacanthos L. to reclaimation of ash landfills from the group of Power Stations „Dolna Odra” S.A. in Nowe Czarnowo, Monografia, XII Międzynarodowa konferencja „Popioły z energetyki” Sopot, 12-14 października 2005.

Niedźwiecki E., Meller E., 1994. Wstępne wyniki badań nad przydatnością odpadów paleniskowych z Z.E. „Dolna Odra" w uprawach rolniczych. / Initial results of research on the usefulness of burner wastes from the „Dolna Odra” Power Plant in agriculture, in: Materiały konferencyjne, Zagospodarowanie odpadów paleniskowych i odpadów z odsiarczania spalin, Świnoujście: 17-18.

Zieliński J., Nowak G., 2004. Ocena wzrostu rokitnika pospolitego Hippophaë rhamnoides rosnącego na odpadach paleniskowych rekultywowanych różnymi metodami. / The estimation of the growth of sea buckthorn Hippophaë rhamnoides $\mathrm{L}$. growing on burner wastes reclaimated by different methods, Folia Univ. Agric Stetin., Agricultura, 242 (98): 203-206.

\section{Kwitnienie róży pomarszczonej (Rosa rugosa Thunb.) uprawianej na odpadach paleniskowych rekultywowanych różnymi metodami}

\section{Streszczenie}

Praca przedstawia wyniki badań nad kwitnieniem róży pomarszczonej uprawianej w warunkach rekultywacji składowisk odpadów paleniskowych prowadzonych w latach 2004-2006. W doświadczeniu uwzględniono sposób przygotowania podłoża i rodzaj zastosowanej żyznej warstwy wierzchniej. Kontrolę stanowiły rośliny rosnące na gruncie rodzimym oraz na surowej skale popiołowej. W ramach badań zmierzono żywotność roślin oraz określono liczbę kwiatów i procent zawiązanych $\mathrm{z}$ nich owoców.

Przeprowadzone badania wskazują, że zastosowane metody rekultywacji miały istotny wpływ na kształtowanie się badanych cech róży pomarszczonej. Porównując metody rekultywacji zauważyć można, że zastosowanie nadkładów istotnie poprawiło warunki ich wzrostu i kwitnienia. Korzystniejsze efekty uzyskano stosując nadkłady z przewagą materii mineralnej. 